\title{
Social Responsibility and its Impact on Competitive Advantage of Service Business Organizations: A field study on mobile phone companies in Yemen
} Abdullah Shuraim ${ }^{1 *}$ and Mohan B. Biradar ${ }^{2}$

${ }^{1}$ Research Scholar, Department of Commerce, Dr. Babasaheb Ambedkar Marathwada University, Aurangabad, Maharashtra 431001, India

${ }^{2}$ Assistant professor, Siddharth College, Dr. Babasaheb Ambedkar Marathwada University, Jafrabad, India.

\begin{tabular}{llllll}
\hline Received: 20.12 .2020 & • & Accepted: 29.12.2020 & • & Published: 02.01.2021 & • Final Version: 04.01.2021
\end{tabular}

\begin{abstract}
This present study aims to investigate the effect of social responsibility (SR) on achieving the competitive advantage of service business organizations. The study is conducted on mobile phone companies in Yemen. The study uses a sample of 99 employees working in the main offices of these companies in Sana'a. The data of the study was collected through a self-administered Likert questionnaire survey. As being the most appropriate method to implement this study, descriptive statistical method was adopted to analyze the results. The findings indicate a positive role of the application of social responsibility in achieving the competitive advantage in mobile phone companies in Yemen. The study recommends that policymakers, regulators and companies should put strict disciplines and adopt different strategies to enhance the role of social responsibility. The study contributes to the strand literature of social responsibility. It addresses the issue of corporate social responsibility in a low-income country which opens an insight for regulators, policymakers, analysts, academicians and managers into the role of corporate social responsibility.
\end{abstract}

Keywords: social responsibility; competitive advantage; services business organizations, Yemen.

\section{Introduction}

Since decades, social responsibility (SR) has been an important consideration for business management. It has been a fundamental characteristic for successful and leading business organizations which make great efforts to integrate it into their performance requirements and incorporate it as one of its top priorities (Rachi, 2013). They believe that social responsibility activities and initiatives support them to reach satisfaction of their various stakeholders. It can be applied in various ways such as donating a portion of income, raising awareness of social issues or encouraging employees to volunteer in the community (Du, Bhattacharya, \& Sen, 2010). Furthermore, social responsibility is considered as an essential strategy for outperforming competitors and gaining competitive advantage. Companies leaders believe that SR is an influential part of companies' reputation and companies can be distinguished by their sources and abilities that they have as well as by their potential contribution in applying SR which is identified as a source of competitive advantage (Militaru \& Ionescu,2006).

Despite the significant importance of SR, its application on the ground remains highly deficient by firms. The failure to apply it, especially in the developing countries, is more evident. It should be realized that making profits is not sufficient to compete with other companies and get success. People want to know how organizations serve the environment and contribute to social issues to assist the

\footnotetext{
* Corresponding Author: iyhomidi@gmail.com
} 
people in the society. On the other hand, the competitive advantage that companies have in the labor market because of its various abilities cannot last indefinitely. In other words, a firm can maintain its long-term competitive advantage only if it focuses its strategies on the benefits it provides to society and the environment and takes into account when making decisions the effect of these decisions on the different parties of the internal and external environment. Hence, it will be clear what is the significance of applying social responsibility to achieve a competitive advantage at the labor market level. In this study and for the purpose of studying the impact of implementing SR on achieving the competitive advantage of business organizations, the researcher selected mobile phone companies as a model for the organizations that offer services in Yemen through their main offices in Sana'a. Specifically, this paper sheds light on the influence of the activities and programs accomplished by these companies on reaching a high level of competitive advantage. Accordingly, the present study aims to examine the role of social responsibility on achieving the competitive advantage of mobile phone companies in Yemen. It seeks to answer the question of "What is the impact of social responsibility on achieving the competitive advantage of mobile phone companies in Yemen?

The present study provides a unique contribution as it examines the concept of CSR in a low-income country; Yemen. Almugari (2020) indicated that there is dearth of studies in the context of Yemeni businesses. Different studies have recommended the need of SCR studies in different contexts (e.g., Farhan et al., 2020; Almaqtari \& Hashed, et al., 2020; Almaqtari \& Shamim et al., 2020; Almaqtari \& Al-Hattami et al., 2020; Al Maqtari \& Farhan et al., 2020). Accordingly, the present study contributes to the strand literature of CSR in Yemen. It opens an insight for regulators, companies, and policy makers for initiating policy measures to enhance CSR practices in Yemen.

The present study is organized as follows: section two presents the conceptual framework and hypotheses formulation. Section three presents literature review. Section four research methodology. Section five demonstrates the respondents' profile and section six estimates the results. Section seven provides a discussion of the results and finally section eight concludes.

\section{The Conceptual Framework and Hypothesis Formulation}

\subsection{The research framework}

The study investigates the effect of SR through five dimensions: 1) Social responsibility towards employees, 2) Social responsibility towards customers, 3) Social responsibility towards suppliers, 4) Social responsibility towards society, and 5) Social responsibility towards total quality. Following is figure (1) which demonstrates the research framework: 


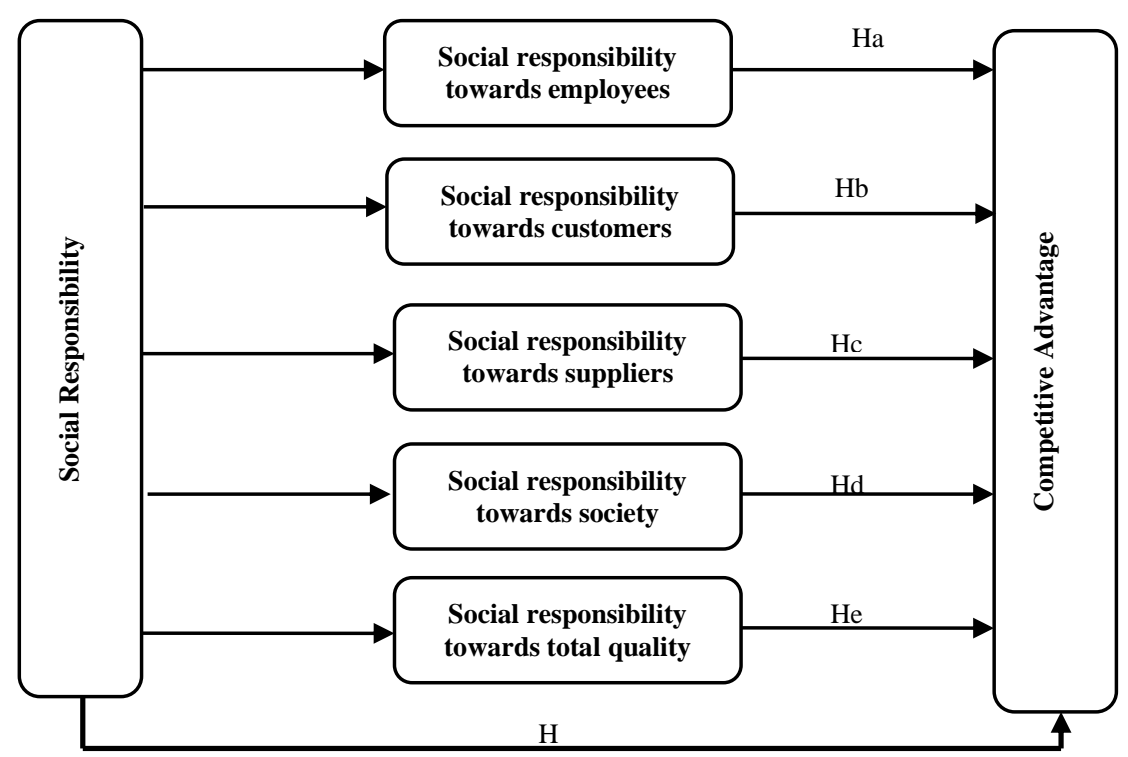

Figure 1. The conceptual framework for research

\subsection{Research Hypothesis}

The main aim of the present study is to examine the impact of CSR on achieving competitive advantage of mobile companies in Yemen. Accordingly, following is the hypothesis of the study:

H1: The application of social responsibility in mobile companies in Yemen contributes to their competitive advantage.

This hypothesis is divided into the following sub-hypotheses:

H1a: There is a significant effect of applying social responsibility towards employees on achieving competitive advantage

H1b: There is a significant effect of applying social responsibility towards customers on achieving competitive advantage

H1c: There is a significant effect of applying social responsibility towards suppliers on achieving competitive advantage.

H1d: There is a significant effect of applying social responsibility towards society on achieving competitive advantage.

H1e: There is a significant effect of applying social responsibility towards total quality on achieving competitive advantage. 


\section{Review of Literature}

\subsection{Social Responsibility}

The development of business organizations' responsibilities toward the community has been accompanied by an increase in community's influences on every member and element in it. This has led these organizations to adopt greater commitments to social needs whether imposed by the law or achieved by initiatives to satisfy society. Thus, the concept of social responsibility (SR) has emerged as an interaction with different factors such as the raising in human awareness and recognition of himself and his society, the great contribution of business organizations to the development of quality of life, the importance of community satisfaction and its acceptance of the goals and actions of business organizations and the high interest shown by major international universities and research centers in teaching courses related to the business relationship with society. Based on these factors, different perspectives have appeared about the concept of social responsibility. According to AlTwaijery (1988), "social responsibility refers to all decisions and actions that consider the development of society as a goal to be reached" (p.21). Al-Sayrafi (2007) has defined SR as " The commitment of the enterprise to the community, in which it operates, by contributing to a wide range of social activities such as fighting poverty, improving services, combating pollution, creating job opportunities, solving transportation problems and others" (p.1). It is also introduced as " taking into account when making decisions the interest of others either inside or outside the organization" (AlAreeqi, 2014, p.34).

\subsubsection{Social responsibility significance}

\section{a- For the organization.}

Fulfilling the social responsibility of business organizations brings many benefits for the organizations themselves. In the forefront of these benefits is to improve the organization's image among employees, clients, and community members in general (Al-Ghalbi \& Al-Amri, 2005). As the social responsibility is voluntary initiatives done by the organization toward direct and indirect parties, the commitment to it will improve the working environment and promote the spirit of cooperation and interdependence among the various parties. In addition, social responsibility is considered as a tool through which organizations can verify their responsibilities towards their stakeholders. Thus, it will have a great concern by organizations to justify their presence in the society (Obaidan, 2005). The adoption of social responsibility by organization enhances its reputation and brand as well as develops the degree of satisfaction of employees and improves the relationship with stakeholders. As a result, this will strengthen the organization's competition and guarantee its survival and continuity (Rachi, 2013)

\section{$b$ - For the society}

The benefits that society will gain from business organizations' interest in adopting a certain type of social responsibility can be summarized as follows:

- Increase social solidarity among different segments of society while creating a high sense of affiliation by individuals with special needs, women, minorities, youth and others.

- Prevail social stability as a result of the availability of social justice and the prevalence of equal opportunities which is the essence of social of business organizations

- Improve the quality of life in society, whether in terms of infrastructure or in culture aspects. 
- Increase awareness of the importance of full integration between society organizations and different interest groups.

- Improve political development based on increasing social awareness at the level of individuals, groups and organizations which will contribute to political stability and a sense of social justice (Al-Ghalbi \& Al-Amri, 2005).

\section{c- For the State}

The state is one of the main beneficiaries of the awareness of business organizations of their social role. This will reduce the burden on the state to fulfill its health, education, cultural and other social tasks and services. (Al-Ghalbi \& Al-Amri, 2005).

\subsubsection{Social responsibility dimensions}

Social responsibility dimensions are the mandatory and voluntary contributions offered by it to society and the environment which are as follows:

\section{a- Social responsibility toward employees}

The organization is committed to providing the services needed to improve the quality of life of its staff in order to create an appropriate environment that encourages the employees to make greater efforts to do their commitments. By these services, the organization will gain the employees' affiliation and loyalty as well as immediate and indirect economic benefits now and in the future. Among the most important contributions to the employees are:

- Provide training programs inside and outside the organization to increase the employees' skills and abilities.

- Spend on some employees who wish to complete their higher education to develop their technical and managerial skills.

- Provide a promotion policy that recognizes the abilities of employees, appreciates their efforts and offers equal opportunities for them.

- Establish a special insurance system to share with the employees and contribute to social insurance for them at a certain proportion of their salaries and wages to obtain an appropriate retirement salary.

- Establish health care and hospital treatment system and pay for medical medicine for the employees and their families.

- Provide employees with wages and salaries that guarantee an adequate standard of living.

- Establish systems incentives and rewards for deserved employees' performance.

- Provide industrial security, work to avoid accidents at the organization and provide a clean, pollution-free environment.

- Distribute a share to the employees from the distributed annual profits (Rachi,2013)

\section{b- Social responsibility toward consumers}

Consumer protection has gained considerable importance in recent years. Its requirements have emerged as an important issue among the social responsibility issues that the organization must take into account in planning and decision - making. The contributions and activities provided by the organization to ameliorate the product quality aim to improve the reputation of the organization primarily for consumers as well as in the industrial and commercial communities. Consequently, the organization's sales share and competitiveness will increase in the local and international markets. The most important contributions that organizations can provide for the consumers are:

- conduct marketing research to identify consumer needs and aspirations.

- Adopt the concept of green marketing and its green marketing including the declaration and promotion that reflect the reality of the organization's products and services and conform to various particularities such as cultural and religious ones. 
- Provide the necessary data on the characteristics of products, the manner in which they are used, the limits of their risks and the validity of their use.

- Commitment to the price that is consistent with consumers' purchasing power.

- The non-use of unhealthy substances in packaging processes, which would expose consumers to many health damages.

- Provide post-sales service, adhere to the warranty date and respond to consumer complaints (Rachi, 2013).

\section{c- Social responsibility towards suppliers}

Since suppliers are important source of information obtained by the organization on the one hand and the basic content of its various needs of raw materials, equipment and funds on the other hand and due to the mutual interests that link the organization and suppliers, the organization must respect their legitimate demands. These demands are to continue importation from them, especially for some types of raw materials needed for production processes, make commitments and truthfulness in dealing, train suppliers on various ways of developing work and engage them in product and process development. (Rachi,2013) .

\section{$d$ - Social responsibility towards society}

This dimension includes the services that provide the public benefit to community members and the participation with the government to offer these services in order to eliminate social problems. The most significant services for society in the area of health, housing, transport, minorities and special groups. They can be through:

- Donating to charitable organizations and non-governmental organizations (NGOs).

- Contributing to setting up educational and technical institutes to improve the efficiency of new graduates and prepare them to enter the labor market. In addition, donating to needy students and encouraging them to continue their higher education as well as contributing to establishing scientific laboratories at some universities.

- Providing equal job opportunities for members of society to alleviate the problem of unemployment and accepting employment of disabled people.

- Providing services to the social groups in society such as the services provided to children and elderly care centers and contributing to the care of disabled people.

- Supporting spending on health agencies and contributing to setting up hospitals for severe diseases and epidemics.

- Contributing to cultural fields by setting up libraries in poor areas, publishing books, financing exhibitions, issuing scientific and cultural magazines to be distributed in seminars and conferences and protecting cultural heritage such as antiquities.

- Supporting sport activities through funding sport clubs and contributing to providing infrastructure, sports facilities and parks for children, women and elderly (Rachi,2013).

\section{e- Social responsibility towards the total quality}

According to Abas, Talhi and Mayoof (2018), achieving the social responsibility is essential to apply the philosophy of total quality. The fact is that a good application of total quality will be when leaders of organizations are ready to fulfill their commitments towards society to guarantee well-quality life. These commitments can be summarized as follows:

- Abiding by administrative controls that result in a positive impact on society in general.

- Developing relationships with stakeholders internally and externally on ethical grounds and in a responsible manner.

- Caring, appreciating, and motivating employees.

- Creating consistency and correlation between the ethical values and professional practices of the organization. 


\subsection{Competitive advantage}

The concept of competitive advantage is viewed as a real revolution in the academic and practical world of business management. Academically, management is no longer perceived as a temporary confrontation with problems that are not of a strategic dimension, but it is viewed as a dynamic and continuous process aimed at addressing many internal and external concerns to achieve the continuous superiority of the organization over others (competitors, suppliers, buyers and other parties with whom it deals). This excellence will not be a short- term business but permanent endeavors to maintain the organization balance vis- $\bar{\alpha}-$ vis other market parties. In practice, managers are keen, according to the new concept, to work tirelessly and continuously, analyze, discover and maintain investment in the competitive advantage of the organization

The competitive advantage refers to the ability of the organization to formulate and apply strategies that make it better placed compared to other organizations working in the same activity. It is achieved through better utilization of the technical, material, financial and organizational capabilities as well as competencies, knowledge and other capabilities of the organization that enable it to implement its competitive strategies (Abubakr, 2004). Competitive advantage is also defined as an advantage or superiority of an organization that is achieved if the organization follows a specific competition strategy (Khalil,1998). It is the company's acquisition of a profit rate above the average prevailing in the industry to which it belongs (Al-Areeqi,2014). Al-Salmi (2001) elaborated that competitiveness is the skill, technology or distinct resource that allows the organization to produce more value and benefits for customers than what competitors offer them. This resource gives the organization its distinction that makes it unique from those competitors from the perspective of customers who get more benefits and values.

\subsubsection{Competitive advantage dimensions}

Dimensions of competitive advantage have been mentioned frequently in scientific literature. In view of many literary references, the dimensions widely agreed among various literature can be represented in the following:

\section{a- Market share}

A market share is an indicator of how much a company sells in the market. Maximizing the market share helps to provide solid ground so that the company can continue its business naturally and effectively. It is defined as the ratio of the total sales of the company's services and products calculated by determining the amount of revenue or profits achieved by company. According to that, the production, distribution, marketing and analysis of the company's market share are directed in the market (Kaplow, 2015). Peter et al. (2014) define it as the company's ability to maximize its sales, increase its profits in the market, attract new customers and pay attention to its current customers. The importance of maximizing the company's market share is evident in improving and developing its performance.

The larger the market share of the company, the more it indicates the sophistication and quality of services and goods it provides. This, in turn, reflects on improving the company's reputation and maintaining its strong position in the market. As the market share plays a pivotal role in maximizing profits, enabling the company to expand the circle of its customers and the market, obtaining a stable return on investment, providing it with a kind of positive stability in the market and making it open to global markets, decision makers and departments have sought to go towards improving the quality 
of its services and products, developing its performance and working hard to provide the appropriate environment for workers and departments that enhance their performance and productivity in order to maximize the market share and raise the company's position at the local and international levels (Economou \& Chatzikonstantinou, 2009).

\section{b- Quality}

Quality is one of the most important dimensions that shows the company how far it has achieved a competitive advantage. The better the quality of services and goods, the more it reflects on the company's performance and its achievement of competitive advantage in the market. Quality is defined as an asset of integrated activities and processes that the company follows as a strategy to improve its production, reduce cost, gain customers satisfaction, expand marketing and distribution and achieve the company's competitive goals (Chen et al., 2013). Grzinic (2007) defined it as a company policy to assess the quality of services and products that meet the customer's expectations.

It is extremely important to design goods and services that are superior to their counterparts in the market. Therefore, the company can distinguish exclusively with the goods it provides, and thus achieve a highly competitive advantage. In the light of the competition witnessed by the market and the changing economic situation, it was imperative that companies strive to make extraordinary efforts to provide and generate distinguished goods and services and improve them in order to gain customer satisfaction, reduce cost, achieve a greater market share and improve the rate of return on investment.

\section{c- High efficiency}

Efficiency is defined as the ratio of outputs to the inputs required for achievement (Robbins, 2005). It is measured by the amount of input needed to produce specific outputs. Inputs are the main factors of production such as human effort, land, capital and technological knowledge. Outputs are the goods and services produced by the company. Work is the means of converting inputs into outputs. The most important issue for efficiency, which concerns most organizations, is worker productivity. It is measured by the number of units produced per worker. If it is assumed that all other variables are constant, the industrial organization that has high worker productivity will have a low cost production and will have a competitive advantage based on the low cost.

\section{d- High innovation}

Innovation is defined as something new or unfamiliar with the way the company operates or in the production it provides. It involves advances in products types, production process, management system, organizational structure and company strategies. It can be the most important signal for competitive advantage- building. In the long run, competition can be seen as a process driven by innovation. Although not all innovations have been successful, successful ones can be the most important source of competitive advantage because they give the organization something unique something that competitors lack (Barney,1991).

\section{e- Quick response to customer:}

To achieve a high response to the customer, the organization must be able to carry out its business better than its competitors and meet their customers' needs effectively. If the organization does so, consumers will value the products more than they value the products of competing organizations. 
Thus, the organization strengthens its competitive advantage. In addition, achieving high quality and innovation is the component of achieving high customer response. Another important factor in responding to the customer is the manufacture of the goods and the provision of services as requested by an individual or group (Hasson et al., 2012).

\subsection{The relationship between social responsibility and competitive advantage:}

These days, many organizations across the world work hard to apply SR activities not only to do their duty towards social issues, but because they do not want to be viewed as inferior or out of touch. They believe that implementing these activities and programs will help them to have a good mental image in the minds of all their stakeholders. As a result, many benefits will be reached such as gaining success and continuity, increasing their competitiveness and becoming the strongest among other competitors (Mohammed \& Shukri, 2013). SR is considered as a means or a tool to reach their strategic objectives one of which is to gain competitive advantage (Du, Bhattacharya \& Sen, 2011).

Ljubojevic, Ljubojevic and Maksimovic, (2012) stated that competitive advantage can be achieved by three processes: strategy, stakeholders and responsibility. In other words, SR's strategy and programs affect competitiveness and lead to various benefits for organizations such as continuous development for their vision, strengthening their relationship with the main stakeholders, constructing their competitive advantage and enhancing their position among other organizations working in the field (El-Garaihy, Mobarak \& Albahussain, 2014). All in all, applying SR can bring organizations uniqueness and differentiation from competitors and support them to have a highranked position (Militaru \& Ionescu, 2006). It strongly motivates them to be innovative reliable on the competitive level.

\section{Research Methodology:}

To reach the study objectives, the descriptive statistical method was applied as the most suitable way to a total understanding of the study problem.

\subsection{Population and sample selection:}

The target population for this study comprises all employees in the four mobile phone companies in Yemen. Convenience sampling was applied to choose the sample of the study. The sample size was 99 employees working in the main offices of these companies in Sana'a. A structured selfadministrated questionnaire was used for data collection. The questionnaire includes three main parts: the first part has been allocated to get general information about respondents. The second part consists of (37) items related to social responsibility dimensions as an independent variable. The third part consists of (9) items related to competitive advantage as a dependent variable.

To measure the effect of social responsibility on competitive advantage, data collection process was mainly done through a five-point Likert questionnaire scaling from one to five where one means strongly disagree and five means strongly agree. The questionnaire's content validity has been confirmed by a set of referees who are either specialists in business administration or academicians referees. The questionnaire items were adjusted according to their comments and modifications. To assess the constructed validity of the questionnaire, exploratory factor analysis was conducted and the results show that the questionnaire has the required validity. The reliability of the questionnaire 
was measured by using Cronbach's alpha coefficient with a total value 0.951 . Table 1 indicates the value of reliability of the instrument used in this study.

Table 1. Cronbach's Alpha values for research variables

\begin{tabular}{cccc}
\hline Variable & Dimensions & $\begin{array}{c}\text { Number } \\
\text { of Items }\end{array}$ & $\begin{array}{c}\text { Cronbach's } \\
\text { alpha }\end{array}$ \\
\hline & Social responsibility towards employees & 9 & 0.855 \\
$\begin{array}{c}\text { Social } \\
\text { Responsibility }\end{array}$ & Social responsibility towards customers & 8 & 0.718 \\
& Social responsibility towards suppliers & 6 & 0.822 \\
$\begin{array}{c}\text { Sompetitive } \\
\text { Advantage }\end{array}$ & Social responsibility towards total quality & 10 & 0.81 \\
& & 9 & 0.911
\end{tabular}

As shown in Table 1, all alpha coefficients were above the cut-off point of 0.70 and indicate an acceptable level of reliability of the questionnaire (Al-Swidi et al., 2014; Al-Swidi and Al Yahya, 2017).

In order to measure the strength of the relationship among the variables of the study, the Pearson correlation test was employed (Sekaran \& Bougie, 2010).

Table 2. Pearson correlation coefficient for all items of research variables

\begin{tabular}{ccc}
\hline Variable & Dimensions & $\begin{array}{c}\text { Pearson correlation } \\
\text { coefficient }\end{array}$ \\
\hline & Social responsibility towards employees & $0.684^{* *}$ \\
& Social responsibility towards customers & $0.623^{* *}$ \\
Social Responsibility & Social responsibility towards society & $0.720^{* *}$ \\
& Social responsibility towards suppliers & $0.801^{* *}$ \\
Competitive Advantage & Social responsibility towards total quality & $0.744^{* *}$ \\
$* *$ correlation is significant at the 0.01 level & $0.643^{* *}$
\end{tabular}

It is clear from Table 2 that there is a high positive correlation between the independent variable (social responsibility) and the dependent variable (competitive advantage). It also indicates high and sufficient validity indicators that can be trusted in the application of the current study, and thus the field is considered valid for what it was designed to measure. After analysis the study instrument, a total of (120) questionnaires were distributed out of which (110) received back and (99) questionnaires were usable (response rate of $82.5 \%$ ). 


\section{Respondents Profile}

To show the demographic characteristics of the respondents used in this study, description analysis was used based on gender, age, education, experience and selected mobile companies as it is shown in Table 3.

Table 3. respondents' profile

\begin{tabular}{cccc}
\hline Items & Options & Frequency & Percentage \% \\
\hline \multirow{2}{*}{ Gender } & Male & 83 & $83.8 \%$ \\
& Female & 16 & $16.2 \%$ \\
Age & $20-30$ & 36 & $36.36 \%$ \\
& $31-40$ & 55 & $55.56 \%$ \\
& $41-50$ & 8 & $0.08 \%$ \\
& 51 and more & 0 & $0 \%$ \\
Education & Primary & 0 & $0 \%$ \\
& Secondary & 3 & $3.0 \%$ \\
& BA degree & 87 & $87.9 \%$ \\
& MA degree & 9 & $9.1 \%$ \\
Experience & $1-5$ years & 29 & $29.3 \%$ \\
& $6-10$ years & 33 & $33.3 \%$ \\
& $11-16$ years & 32 & $32.3 \%$ \\
Selected mobile & years and more & 5 & $5.1 \%$ \\
companies & Y & 29 & $29.29 \%$ \\
& MTN & 26 & $26.26 \%$
\end{tabular}

According to Table 3, it is indicated that males constitute the majority of workers (research sample) in the mobile companies in question. They represent (83.8\%) while females represent (16.2\%). This may be due to the low demand of females for technical education required to work in these companies, or it may be that the girls have few opportunities to join these companies. In terms of qualification, the majority of workers in mobile companies are those with a BA degree $(87.9 \%)$ and MA degree (9.1\%). This indicates the interest of these companies to attract highly qualified people whose knowledge affects positively on the performance's quality. In terms of age, more than half of the participants are between the ages of (31-40) years (55.5\%) with an experience ranging between (6-16) years. This shows the accumulated and excellent experience of the staff in these companies.

Table 4. The general average of the results

\begin{tabular}{lccc}
\hline \multicolumn{1}{c}{ Variables } & Average & $\begin{array}{c}\text { Standard } \\
\text { Deviation }\end{array}$ & $\begin{array}{c}\text { Degree of } \\
\text { Agreement }\end{array}$ \\
\hline Social responsibility towards employees & 3.5208 & .73234 & $70.4 \%$ \\
Social responsibility towards customers & 3.9015 & .62558 & $78 \%$ \\
Social responsibility towards society & 3.7205 & .69041 & $74.4 \%$ \\
Social responsibility towards suppliers & 3.5152 & .67084 & $70.3 \%$ \\
Social responsibility towards total quality & 3.6323 & .69043 & $72.6 \%$ \\
Competitive Advantage & 3.8294 & .56440 & $76.6 \%$
\end{tabular}


Based on table (4), The highest of the variables agreeing was the second variable (social responsibility towards customers) with an average of (3.9) and the standard deviation was (0.623) and with a degree of agreement (78\%). This indicates that the research sample agrees with a higher percentage that there is social responsibility towards customers. The dependent variable (competitive advantage) came in second place with an average of (3.83) and a standard deviation of (0.564) and a degree of agreement (76.6\%), which means that there is a good competitive advantage for mobile phone companies in Yemen. The variable (social responsibility towards society) came in third place with an average of (3.72) and the standard deviation was (0.690) and a degree of agreement (74.4\%), which means that there is a social responsibility towards society. The variable (social responsibility towards workers) came in fourth place, with an average of (3.52), and the standard deviation was $(0,732)$ and with a degree of agreement $(70.4 \%)$, which means that there is a social responsibility towards workers, but at a lower rate than its predecessors. The variable (social responsibility towards suppliers) came in last place, with an average of (3.52), and the standard deviation was (0.671) and with a degree of agreement (70.3\%), which is a medium degree, which means that there is social responsibility towards suppliers, but less than the rest of the variables.

\section{Hypotheses Testing:}

Regression analysis was applied to test the main hypothesis and the sub-hypotheses postulated in this study. For the main hypothesis, it is anticipated that the social responsibility application in mobile phone companies contributes to achieving their competitive advantage. Results in Table 5 Indicate that $(43.5 \%)$ variances in achieving the competitive advantage can be explained by the application of social responsibility in mobile companies $\left(\mathrm{R}^{2}=.435, \mathrm{P}<0.05\right)$. The value of $(\beta)$, which amounted (.660), means that a single-degree increase in the application of social responsibility will lead to achieving the competitive advantage. The significance of this effect is confirmed by the value of $(\mathrm{F})$ which equals $(74.709)$. Also, the value of $(\mathrm{R})$, which equals $(66 \%)$ indicates that $(\mathrm{H})$ is supported.

Table 5. regression analysis of social responsibility with competitive advantage

\begin{tabular}{ccccccc}
\hline $\mathrm{R}$ & $\mathrm{R}^{2}$ & $\mathrm{~F}$ & $\mathrm{DF}$ & Sig $^{*}$ & $\beta$ \\
\hline \multirow{2}{*}{0.660} & \multirow{2}{*}{435} & \multirow{2}{*}{74.709} & Regression & 1 & & \\
& & & Residual & 97 & 0.000 & .660
\end{tabular}

The first sub-hypothesis is to evaluate whether there is a significant effect between applying social responsibility towards employees and achieving competitive advantage.

Table 6 shows the result of this hypothesis. It clearly indicates that variances in achieving the competitive advantage can be as a result of the application of social responsibility towards the employees $\left(\mathrm{R}^{2}=.283, \mathrm{P}<0.05\right)$. The value of $(\beta)(.532)$ means that a single-degree increase in the application of social responsibility towards the employees will result in achieving the competitive advantage. These values indicate that there is a significant effect between applying social responsibility towards the employees and achieving the competitive advantage. Thus, $\mathrm{H}_{\mathrm{a}}$ is supported. 
Table 6. Regression analysis of social responsibility towards employees with competitive advantage

\begin{tabular}{|c|c|c|c|c|c|c|c|}
\hline Particulars & $\mathrm{R}$ & $\mathrm{R}^{2}$ & $\mathrm{~F}$ & $\overline{D F}$ & & Sig $^{*}$ & $\beta$ \\
\hline \multirow{3}{*}{$\begin{array}{l}\text { Competitive } \\
\text { Advantage }\end{array}$} & \multirow{3}{*}{0.532} & \multirow{3}{*}{.283} & \multirow{3}{*}{38.223} & Regression & 1 & \multirow{3}{*}{0.000} & \multirow{3}{*}{.532} \\
\hline & & & & Residual & 97 & & \\
\hline & & & & Total & 98 & & \\
\hline
\end{tabular}

As can be seen in Table 7, the results of regression analysis of $\mathrm{H}_{\mathrm{b}}$ show that there is a significant effect between applying social responsibility towards customers and achieving the competitive advantage through the value of $\left(\mathrm{R}^{2}\right)$ which is amounted (43\%) and indicates that this value can be an outcome of the application of social responsibility towards the customers $\left(\mathrm{R}^{2}=.430, \mathrm{P}<0.05\right)$. The value of $(\beta)$,which is (.656), means that a single-degree increase in the application of social responsibility towards the customers will contribute in achieving the competitive advantage. The values confirm that there is a significant effect between applying social responsibility towards the customers and achieving the competitive advantage. Thus, $\mathrm{H}_{\mathrm{b}}$ is supported.

Table 7. Regression analysis of social responsibility towards customers with competitive advantage

\begin{tabular}{cccccccc}
\hline Particulars & $\mathrm{R}$ & $\mathrm{R}^{2}$ & $\mathrm{~F}$ & $\mathrm{DF}$ & Sig $^{*}$ & $\beta$ \\
\hline Competitive & \multirow{2}{*}{0.656} & \multirow{2}{*}{430} & \multirow{2}{*}{73.267} & Regression & 1 & & \\
Advantage & & & & Residual & 97 & 0.000 & .656
\end{tabular}

For the third sub-hypothesis, Table 8 indicates that variances in achieving competitive advantage can be explained by the application of social responsibility towards suppliers $\left(\mathrm{R}^{2}=.290, \mathrm{P}<0.05\right)$. The value of $(\beta)$, which is amounted (.538), means that a single-degree increase in the application of social responsibility towards the suppliers will lead to achieve the competitive advantage. These values explain that there is a significant effect between applying social responsibility towards the suppliers and achieving the competitive advantage. Therefore, $\mathrm{H}_{\mathrm{c}}$ is supported.

Table 8. Regression analysis of social responsibility towards suppliers with competitive advantage

\begin{tabular}{|c|c|c|c|c|c|c|c|}
\hline Particulars & $\mathrm{R}$ & $\mathrm{R}^{2}$ & $\mathrm{~F}$ & DF & & Sig* & $\beta$ \\
\hline \multirow{3}{*}{$\begin{array}{l}\text { Competitive } \\
\text { Advantage }\end{array}$} & \multirow{3}{*}{0.538} & \multirow{3}{*}{.290} & \multirow{3}{*}{39.585} & Regression & 1 & \multirow{3}{*}{0.000} & \multirow{3}{*}{.538} \\
\hline & & & & Residual & 97 & & \\
\hline & & & & Total & 98 & & \\
\hline
\end{tabular}

For the fourth sub-hypothesis, it is expected that there is a significant effect between applying social responsibility towards society and achieving the competitive advantage. Results in table 9 show that variances in achieving competitive advantage can be elaborated by the application of social responsibility towards the society $\left(\mathrm{R}^{2}=0.257, \mathrm{P}<0.05\right)$. The value of $(\beta)$, which is (.507), means that a single-degree increase in the application of social responsibility towards the society will lead to achieve the competitive advantage. This emphasizes that there is a significant effect between applying social responsibility towards the society and achieving the competitive advantage. Thus, $\mathrm{H}_{\mathrm{d}}$ is supported. 
Table 9. Regression analysis of social responsibility towards society with competitive advantage

\begin{tabular}{cccccccc}
\hline Particulars & $\mathrm{R}$ & $\mathrm{R}^{2}$ & $\mathrm{~F}$ & $\mathrm{DF}$ & Sig $^{*}$ & $\beta$ \\
\hline Competitive & & & & & Regression & 1 & \\
Advantage & 0.507 & .257 & 33.557 & Residual & 97 & 0.000 & .507 \\
& & & & Total & 98 & &
\end{tabular}

Based on the results in Table 10, it is indicated that variances in achieving competitive advantage can be explained by the application of social responsibility towards total quality $\left(R^{2}=0.328\right.$, $\mathrm{P}<0.05)$. The value of $(\beta)$, which is amounted (.573), means that a single-degree increase in the application of social responsibility towards the total quality will lead to achieve the competitive advantage. Results of the analysis confirm that there is a significant effect between applying social responsibility towards the total quality and achieving the competitive advantage. Therefore, $\mathrm{H}_{\mathrm{e}}$ is supported.

Table 10. Regression analysis of social responsibility towards total quality with competitive advantage

\begin{tabular}{|c|c|c|c|c|c|c|c|}
\hline Particulars & $\mathrm{R}$ & $\mathrm{R}^{2}$ & $\mathrm{~F}$ & \multicolumn{2}{|c|}{ DF } & Sig* $^{*}$ & B \\
\hline & & & & Regression & 1 & & \\
\hline Competitive & 0.573 & .328 & 47.397 & Residual & 97 & 0.000 & .573 \\
\hline & & & & Total & 98 & & \\
\hline
\end{tabular}

\section{Results and discussion}

This study investigates how competitive advantage can be affected by social responsibility applied by mobile phone companies. After the questionnaire survey and analysis, the relevant research results can be described as follows:

\subsection{Social responsibility towards employees:}

Analysis has shown that mobile phone companies provide an appropriate environment for their employees to help them do their job very well.They have a safety system for workers and provide financial assistance to them which contributes to enhancing the institutional loyalty of the employees. Furthermore, They are keen to train their staff with a good rate, as the degree of approval for this item has reached (75.8\%) which is a large percentage especially in an important item such as the training item. As a result, this contributes to staff development and upgrading. On the other hand, there are items where companies performance is low in terms of applying social responsibility to workers such as the poor distribution of part of corporate profits to workers, the weak participation of employees in corporate decision - making and the poor interest of companies in solving the employees' own problems.

\subsection{Social responsibility towards customers:}

Mobile phone companies do their business on the basis of their belief that customers are the basis of their existence. They grant customers additional benefits free of charge. These items gained (75.9\%) of the total degree of approval and are considered the least in applying social responsibility towards customers in these companies. They are interested in their customers, especially in implementing agreements, adhering to the price that suits their purchasing power and trying to solve their complaints urgently. These items received an average of (80.2\%) of the total approval score. They are also concerned with the continuous improvement of services to achieve the interests of all parties. 
They conduct marketing research to identify consumer needs and measure customers' opinions about their services. These terms have received an average of (77.4\%) of the total degree of approval.

\subsection{Social responsibility towards suppliers:}

The interest of mobile phone companies in applying social responsibility towards suppliers is less than other hubs. It got only an average of (70.3\%). The companies in question believe in the importance of the role of suppliers in providing outstanding customers service. They build a strong relationship with them. the approval rating for these items has reached (75\%). On the other hand, there is a lack of the role of companies in training suppliers on how they develop their business and there is a weakness in involving suppliers in developing the company's processes and products. The approval rate for these two items has reached about (65.5\%).

\subsection{Social responsibility towards society:}

Companies in question have a positive contribution to society in terms of the compatibility of their missions and goals with the surrounding society. They also make donation for charitable projects that benefit some of the community members and contribute to raising community awareness on various issues. These contributions amounted to $(77.5 \%)$ of the total approval score. The contribution of these companies in providing job opportunities for youth, improving public services for the community or supporting small projects for special groups reached $(71.3 \%)$ of the total degree of approval.

\subsection{Social responsibility towards total quality:}

The companies in question are well concerned with customers satisfaction (internal and external). They also have a good communication and information system. These two items have a degree of approval of the participants (77.4\%). They are interested in analyzing quality information, achieving total quality management and studying the customers' needs. The proportion of attention to these items is about (73\%) approval rating. On the other hand, there is a lack regarding the work of companies in the principles of transparency and accountability, as well as a lack of continuous monitoring and evaluation of the improvement process. The approval rating of these items has reached around $(69 \%)$.

\subsection{Competitive advantage:}

As expressed by the responses of the participants, there is a concern and interest among the companies in question to achieve the competitive advantage. The average of approval rating of this variable has reached (76.6\%) which is the second highest average after the average of social responsibility towards customers. These companies are characterized by having well-known brands among consumers, respected and appreciated treatment of employees towards customers and low price of products. The degree of approval for these items has reached an average of (86.4\%). In addition, the customer can obtain the service in a short time as well as the resources with the required specifications due to the good relationship with the suppliers. The customer receives the service wherever and at high quality. These terms have reached an average of approval rating of approximately (74.5\%). On the other hand, there are shortcomings in achieving some dimensions of the competitive advantage such as achieving an increase in productivity each year, achieving an 
increase in profitability as a result of a good relationship with suppliers and achieving an increase in profit margin annually. These items have obtained a degree of approval of about (69\%).

\section{Conclusion}

The current study aimed to examine the effect of social responsibility on achieving the competitive advantage of mobile phone companies in Yemen. A questionnaire survey was used to collect the data needed for the present study. A sample of 99 employees working in the main offices of these companies in Sana'a were involved in this study. Descriptive statistics and simple random sampling were used to estimate the results. The findings of the study revealed that there is statistically significant effect of social responsibility dimensions on the competitive advantage of mobile phone companies in Yemen. The study has a unique contribution to the strand literature of social responsibility. Further, the study has several implications for regulators, managers, policymakers, academicians and other interested parties. The study recommend the need to raise awareness among mobile companies managers of the importance of social responsibility. In addition, corporate administration has to take a clear strategy and systematic plans for social responsibility programs. It is also recommended that the role of the state must be effective by enacting strict laws that impose on organizations the adoption of the concept of social responsibility and also by motivating the organizations that play a positive social role to create competition between organizations. Moreover, it is suggested that Establishing a technical training center specialized in the technical aspects of telecommunications in particular and the administrative and executive aspects in general in order to improve the performance of the staff, which is mainly reflected in the products of companies provided to consumers. The study also Ensures that employees are involved in corporate decisionmaking and distribute a portion of the companies' profits and shares according to certain criteria such as seniority, performance, initiatives and innovations in order to gain employee's loyalty and productivity. It confirms that there is a need to pay attention to contributing in improving social services and supporting small projects in particular for special groups (women, the disabled and the marginalized) through coordination and networking with civil society organizations and local councils. The relationship with suppliers should be improved and suppliers should be involved in developing companies' products and processes through training and building a distinct relationship with them, so that the bottom line is high quality services provided by mobile phone companies. 


\section{References}

[1] Abas, S.B., Talhi, F.A. \& Mayoof, H. (2018). The effect of applying total quality management on the social dimension of the organization. Journal of Economics and Law, 1, 171-193. Retrieved from www.univsoukahras.dz/ar/revue/ecodroit

[2] Abubakr, M. M. (2004). Human resources: An introduction to competitive advantage. Alexandria: University House.

[3] Al Maqtari, F. A., Farhan, N. H., Al-Hattami, H. M., \& Khalid, A. S. (2020). Impact of country-level corporate governance on entrepreneurial conditions. Cogent Business \& Management, 7(1), 1797261. https://doi.org/10.1080/23311975.2020.1797261

[4] Al-Areeqi, M. M. (2014). Strategic management ( $3^{\text {rd }}$ ed.). Sana'a: Al-Amin Center for Printing and Publishing.

[5] Al-Ghalbi, T. M. \& Al-Amri, S. M. (2005). Social responsibility and business ethics-Business and society. Amman: Wael Publishing House.

[6] Al-Salmi, A. (2001). Strategic human resource management. Cairo: Gharib House for Publishing and Printing.

[7] Al-Swidi, A., \& Al Yahya, M. (2017). Training transfer intention and training effectiveness. International Journal of Organizational Analysis. 25(5), 839-860.

[8] Al-Swidi, A., Huque, S. M. R., Hafeez, M. H., \& Shariff, M. N. M. (2014). The role of subjective norms in theory of planned behavior in the context of organic food consumption. British Food Journal. 116(10), 1561-1580.

[9] Al-Syrafi, M. (2007). The social responsibility of the administration. Alexandria: Al-Wafaa for Printing.

[10] Al-Twaijery, M. B. E. (1988). Social responsibility in the private sector in Saudi Arabia. The Arab Journal of Administration, 4. Retrieved from www.arado.org/aja.

[11] Almaqtari, F. A., Al-Hattami, H. M., Al-Nuzaili, K. M., \& Al-Bukhrani, M. A. (2020). Corporate governance in India: A systematic review and synthesis for future research. Cogent Business \& Management, 7(1), 1803579. https://doi.org/10.1080/23311975.2020.1803579

[12] Almaqtari, F. A., Hashed, A. A., Shamim, M., \& Al-ahdal, W. M. (2020). Impact of corporate governance mechanisms on financial reporting quality: a study of Indian GAAP and Indian Accounting Standards. Problems and Perspectives in Management, 18(4), 1.-13. https://doi.org/10.21511/ppm.18(4).2020.01

[13] Almaqtari, F. A., Shamim, M., Al-Hattami, H. M., \& Aqlan, S. A. (2020). Corporate governance in India and some selected Gulf countries. International Journal of Managerial and Financial Accounting, 12(2), 165-185. https://doi.org/10.1504/IJMFA.2020.109135

[14] Almugari, F. A. M. (2020). The Influence of Selected Marketing Strategies on the Brand Favorability: A Special Reference to the Yemeni Market. Studies in Economics and Business Relations, 1(1), 37-47. https://doi.org/10.48185/sebr.v1i1.53

[15] Barney, J. B. (1991). Firm Resources and sustained competitive Advantage, Journal of Management, 17(1), 99-120.

[16] Chen, Y., Hsu, J., Huang, M. \& Yang, P. (2013). Quality, Size, and Performance of Audit Firms. The International Journal of Business and Finance Research, 7(5), 89-105.

[17] Du, S., Bhattacharya, C. B., \& Sen, S. (2010). Corporate social responsibility and competitive advantage: Overcoming the trust barrier. Management Science, 57(9), 1528-1545.

[18] Economou, V.P., \& Chatzikonstantinou, P.G. (2009). Gaining Company's Sustained Competitive Advantage, Is Really a Necessary Precondition for Improved Organizational Performance? The Case of TQM. European Research Studies, 12(3), 83-100.

[19] El-Garaihy, W. H., Mobarak, A. K. M., \& Albahussain, S. A. (2014). Measuring the impact of corporate social responsibility practices on competitive advantage: A mediation role of reputation and customer satisfaction. International Journal of Business and Management, 9(5), 109- 124

[20] Farhan, N., Tabash, M., Almaqtari, F., \& Yahya, A. (2020). Board composition and firms' profitability: Empirical evidence from pharmaceutical industry in India. Journal of International Studies, 13(3), 180194. https://doi.org/10.14254/2071- 8330.2020/13-3/12 
[21] Grzinic, J. (2007). Concepts of Service Quality Measurement in Hotel Industry. Ekonomska Misao I Praksa, 1, 81-98.

[22] Hasson, A., Fadhel, A. S. \& Amer, F. (2012). The effect of the educated organization on achieving competitive advantage. Journal of Baghdad College of Economic sciences, 32, 1-34.

[23] Kaplow, L. (2015). Market Definition, Market Power. Forthcoming in the International Journal of Industrial Organization, 826, 1-29.

[24] Khalil, N. M. (1998). Competitive advantage in business. Cairo: Alexandria Center.

[25] Ljubojevic, C., Ljubojevic, G., \& Maksimovic, N. (2012). Social responsibility and Competitive Advantage of the Companies in Serbia. In MIC 2012: Managing Transformation with Creativity; Proceedings of the 13th International Conference, Budapest, 22-24 November 2012 [Selected Papers] (pp. 555-569). University of Primorska, Faculty of Management Koper.

[26] Militaru, G., \& Ionescu, S. (2006). The competitive advantage of corporate social responsibility. "University Politehnica" of Bucharest Scientific Bulletin, Series D: Mechanical Engineering, 68(2), 89-95.

[27] Mohammed, M.S. \& Shukri, A.M. (2013). The role of social responsibility in increasing the competitiveness of communication companies. Cairo: Arab Administrative Development Organization.

[28] Obaidan, F. L. N. (2005). Accounting for social responsibility Islamic banks. Iraq: University of Basra.

[29] Peter, P.W., Namusonge, M., Waema, C., \& Ngonzo, C.L. (2014). Competitive Strategies' Effects on the Market Share of Independent Petroleum Companies in Kenya. International Journal of Innovative Research and Development, 3(5): 149-153.

[30] Rachi, T. (2013). The adoption of adopting a social responsibility approach as an input to strengthen the entrepreneurship and the competitiveness of business organizations. The 9th international scientific conference for organized Islamic economics and finance. Turkey.

[31] Robbins, Stephen P.2005, Organizational Behavior, (7th ed). Prentic- Hall India, New Delhi.

[32] Sekaran, U. and Bougie. R. (2010). Researchs for business: A skill building approach, (5th ed). Chichester: John Wiley \& Sons. 